Jurnal Sulolipu : Media Komunikasi Sivitas Akademika dan Masyarakat

Vol. 19 No.12019

e-issn : 2622-6960, p-issn : 0854-624X

\title{
UJI KOMPARATIF KEMAMPUAN DAUN LAVENDER (Lavandula angustifolia) DAN DAUN BUNGA TAHI KOTOK (Tagetes erecta) DALAM MEMATIKAN NYAMUK DENGAN METODE IONISASI Ashari Rasjid ${ }^{1}$ dan Atira Afri Lusiana ${ }^{2}$ \\ 1.2 Jurusan Kesehatan Lingkungan Politeknik Kesehatan Kemenkes Makassar Asharirasjid63@gmail.com
}

\begin{abstract}
A vector is an insect or animal that can carry germs and transmit it to others so that the person will become sick. The spread of various diseases by mosquitoes is a very serious health problem, as for some diseases caused by mosquitoes such as dengue fever, Japanese encephalitis, malaria, filariasis. So the mosquito population must be suppressed. The purpose of this study was to determine how much the ability of extracts of lavender (Lavandula angustifolia) and Tahi kotok (Tagetes erecta) in killing mosquitoes. The type of research used was experimental research. Samples were 25 mosquitoes with concentrations of 15\%,20\%,25\% and replicated 3 times. Data were analyzed using T-Test. The results of this study showed $15 \%, 20 \%, 25 \%$ Lavender leaf extract was declared capable after 2 hours of observation with the average number of dead mosquitoes reaching (96\%). Whereas the 15\%, 20\%, 25\% extracts of Tahi kotok are said to be effective after 2 hours of observation with the average number of dead mosquitoes reaching (88\%). The conclusion obtained with the same dose is that lavender leaf extract is more effective compared to Tahi kotok leaf extract. It is recommended that further researchers be able to see how much the ability of Lavender leaf extract and Kotok Tahi leaf if it does not use chemicals such as methanol.
\end{abstract}

Keywords: Lavender leaf extract, Tahi kotok leaf extract, ionization method.

\section{ABSTRAK}

Vektor adalah serangga atau binatang yang dapat membawa bibit penyakit dan menularkan kepada orang lain sehingga orang tersebut akan menjadi sakit. Penyebaran berbagai penyakit oleh nyamuk merupakan suatu masalah kesehatan yang sangat serius, adapun beberapa penyakit yang disebabkan oleh nyamuk seperti demam berdarah, Japanese encephalitis, malaria, filariasis. Sehingga populasi nyamuk harus ditekan. Tujuan penelitian ini adalah untuk mengetahui seberapa besar kemampuan ekstrak daun lavender (Lavandula argostifolisa) dan tahi kotok (Tagetes erecta) dalam mematikan nyamuk.Jenis penelitian yang digunakan adalah Penelitian eksperimen. Sampel 25 ekor nyamuk dengan konsentrasi masing-masing $15 \%, 20 \%, 25 \%$ dan dilakukan 3 kali replikasi. Data dianalisis dengan mengggunakan uji TTest. Hasil penelitian ini menunjukkan ekstrak daun Lavender $15 \%, 20 \%, 25 \%$, dinyatakan mampu setelah 2 jam pengamatan dengan jumlah nyamuk yang mati rata - rata mencapai (96\%). Sedangkan pada ekstrak daun tahi kotok 15 $\%, 20 \%, 25 \%$ diinyatakan efektif setelah 2 jam pengamatan dengan jumlah nyamuk yang mati rata -rata mencapai (88 \%). Kesimpulan yang didapatkan dengan dosis yang sama yaitu ekstrak daun lavender lebih efektif di bandingkan ekstrak daun tahi kotok. Disarankan agar peneliti selanjutnya dapat melihat seberapa besar kemampuan ekstrak daun Lavender dan daun Tahi Kotok jika tidak menggunakan bahan kimia seperti methanol.

Kata Kunci : Ekstrak Daun Lavender, Ekstrak Daun Tahi kotok, metode ionisasi.

\section{PENDAHULUAN}

Vektor adalah serangga atau binatang yang dapat membawa bibit penyakit dan menularkan kepada orang lain sehingga orang tersebut akan menjadi sakit. Salah satunya adalah nyamuk, Nyamuk merupakan serangga pengganggu yang dapat menularkan berbagai macam penyakit berbahaya. Penyebaran berbagai penyakit oleh nyamuk merupakan suatu masalah kesehatan yang sangat serius. Makin tinggi tinggi keinginan manusia baik dalam kenyamanan hidup serta kesadaran akan mutu kesehatan makin tangkap dalam penaganan kehadiran insektisida ini. Nyamuk tergolong serangga yang cukup tua di alam, karena telah melewati proses evolusi yang panjang. Oleh karena itu, insekta ini memiliki sifat yang spesifik dan sangat adaftif tinggal bersama manusia. (Singgih dan Upik,2006)

Nyamuk tersebar luas di seluruh dunia mulai dari daerah kutub sampai ke daerah tropika, dapat dijumpai pada ketinggian 5.000 meter di atas permukaan tanah di daerah pertambangan. Nyamuk di Indonesia terdiri atas 457 spesies, diantaranya 80 spesies Anopheles, 125 aedes, 82 culex, 8 Mansonia, sedangkan sisanya tidak termasuk begitu menganggu (O'Connor dan Sopa, 1981)

Melihat tingginya jumlah penyakit dan kematian yang disebabkan oleh nyamuk sehingga muncul beberapa Pengendalian nyamuk dengan menggunakan beberapa metode, seperti metode lingkungan, biologis, dan kimia.Salah satu cara yang lebih ramah 
Jurnal Sulolipu : Media Komunikasi Sivitas Akademika dan Masyarakat

Vol. 19 No.12019

e-issn : 2622-6960, p-issn : 0854-624X

lingkungan adalah memanfaatkan tanaman anti nyamuk (insektisida hidup pengusir nyamuk).

Tanaman hidup pengusir nyamuk adalah jenis tanaman yang kondisi hidup mampu menghalau nyamuk Tanaman lavender (lavandula angustifolia) merupakan salah satu tanaman yang dapat digunakan sebagai insektisida alami, karena efektif pengendalikan serangga (nyamuk). Hal ini disebabkan tanaman lavender mempunyai kairomon sebagai zat kimia yang menimbulkan aroma yang tidak disenangi oleh nyamuk. Bukan hanya tanaman lavender adapula jenis tanaman yang banyak tumbuh di daerah Tropis yaitu bunga tai kotok atau masyarakat Sulawesi lebih mengenal tanaman ini dengan nama Bunga Tai ayam. Adapun kandungan pada bunga Tahi kotok (Tagetes erecta) memiliki kandungan bau busuk yang dikeluarkan oleh tahi kotar/ tahi ayam (tagetes erecta) yang sangat tidak disukai oleh nyamuk.

\section{BAHAN DAN METODE}

1. Lokasi Penelitian:

\begin{tabular}{llr}
\multicolumn{1}{c}{ Penelitian } & ini dilaksanakan di \\
Laboratorium & Terapan & Poltekkes \\
Makassar & Jurusan & Kesehatan \\
Lingkungan. & &
\end{tabular}

2. Desain dan Variabel Penelitian Jenis penelitian ini adalah jenis penelitian eksperimen yaitu perlakuan uji kemampuan ekstrak daun lavender ( Lavandula argostifolia)15\% 20\% dan 25\%. dan daun tahi kotok ( Tagetes erecter) $15 \% 20 \%$ dan $25 \%$ dalam mematikan nyamuk.

Adapun variabel penelitian pada penelitian ini terdiri dari 3 variabel. Yaitu variabel bebas yang terdiri dari kemampun ekstrak 15\% 20\% 25\%. variabel terikat yaitu kematian nyamuk, serta variabel pengganggu yang terdiri dari suhu dan kelembaban.

\section{Populasi dan Sampel}

Populasi dalam penelitian ini adalah semua jenis jentik yang diperoleh di lingkungan rumah, dan dikembang biakkan mulai dari instar III sampai menjadi nyamuk dewasa.

Sampel dalam penelitian ini adalah 25 ekor nyamuk dan ekstrak daun Lavender (Lavandula argostafolia) Dan Bunga tahi kotok (Tagetes erectes) dengan konsentrasi masing-masing $15 \% 20 \% 25 \%$ dan dilakukan 3 kali replikasi.

4. Pengumpulan data

Sumber data terdiri dari 2 yaitu data primer yang diambil secara langsung oleh peneliti dan data sekunder data yang diperoleh dari berbagai referensi baik artikel-artikel, buku, maupun literatur yang lain yang dianggap dapat mendukung teori yang ada, serta dianggap dapat mendukung teori yang ada serta dianggap memiliki keterkaitan dengan penelitian ini.

\section{Analisa Data (Jika memakai program statistic, tuliskan uji utama apa yang digunakan) \\ Analisa data dilakukan dengan} menggunakan tabel beserta pembahasannya dan disimpulkan dengan menggunakan menggunakan uji independen $T$ test.

HASIL

1. Hasil pengamatan nyamuk yang mati setelah pemajanan dosis $15 \% 20 \%$ dan 25 $\%$ ekstrak daun Bunga Lavender (Lavandula argostifolia) pada pemaparan, dapat di lihat pada tabel di bawah ini

Tabel 1

Pengamatan Jumlah Kematian Nyamuk Dengan

Ekstrak Daun Lavender 15\%

\begin{tabular}{|c|c|c|c|c|c|}
\hline \multirow[t]{2}{*}{$\begin{array}{c}\text { Waktu } \\
\text { pengamatan }\end{array}$} & \multicolumn{3}{|c|}{$\begin{array}{c}\text { Jumlah Nyamuk } \\
\text { Yang Mati Dalam } \\
\text { Tiga Replikasi } \\
\text { (Ekor) } \\
\end{array}$} & \multirow[t]{2}{*}{$\begin{array}{c}\text { Rata } \\
- \\
\text { rata }\end{array}$} & \multirow[t]{2}{*}{$\begin{array}{c}\text { Persen } \\
\text { tase } \\
(\%)\end{array}$} \\
\hline & I & II & III & & \\
\hline 20 menit & 2 & 4 & 3 & 3 & 12 \\
\hline 40 menit & 4 & 6 & 7 & 6 & 24 \\
\hline 60 menit & 9 & 8 & 12 & 10 & 40 \\
\hline 80 menit & 14 & 13 & 15 & 14 & 56 \\
\hline 100 menit & 16 & 15 & 17 & 16 & 64 \\
\hline 120 menit & 16 & 18 & 21 & 18 & 74 \\
\hline
\end{tabular}

Sumber: Data Primer 2018 
Jurnal Sulolipu : Media Komunikasi Sivitas Akademika dan Masyarakat

Vol. 19 No.12019

e-issn : 2622-6960, p-issn : 0854-624X

Tabel 2

Pengamatan Jumlah Kematian Nyamuk Dengan Ekstrak Daun Lavender 20\%

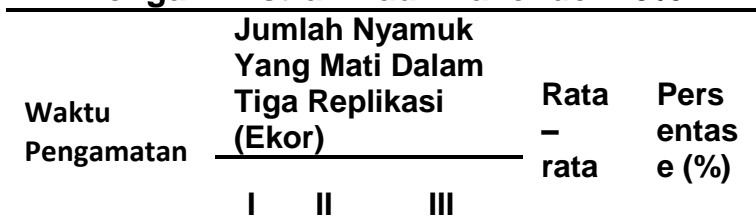

\begin{tabular}{cccccc}
\hline 20 menit & 4 & 4 & 3 & 4 & 16 \\
40 menit & 7 & 7 & 6 & 7 & 28 \\
60 menit & 15 & 11 & 10 & 12 & 48 \\
\hline 80 menit & 17 & 16 & 12 & 15 & 60 \\
100 menit & 19 & 19 & 15 & 18 & 74 \\
120 menit & 20 & 21 & 20 & 20 & 80 \\
\hline
\end{tabular}

Sumber : Data Primer 2018

Tabel 3

Pengamatan Jumlah Kematian Nyamuk Dengan Ekstrak Daun Lavender 25\%

\begin{tabular}{|c|c|c|c|c|c|}
\hline \multirow[t]{2}{*}{$\begin{array}{l}\text { Waktu } \\
\text { pengam } \\
\text { atan }\end{array}$} & \multicolumn{3}{|c|}{$\begin{array}{l}\text { Jumlah Nyamuk } \\
\text { Yang Mati Dalam } \\
\text { Tiga Replikasi } \\
\text { (Ekor) }\end{array}$} & \multirow[t]{2}{*}{$\begin{array}{c}\text { Rata } \\
\text { - rata }\end{array}$} & \multirow[t]{2}{*}{$\begin{array}{c}\text { Persen } \\
\text { tase } \\
(\%)\end{array}$} \\
\hline & I & II & III & & \\
\hline 20 menit & 5 & 5 & 3 & 4 & 16 \\
\hline 40 menit & 10 & 8 & 8 & 9 & 36 \\
\hline 60 menit & 20 & 13 & 12 & 15 & 60 \\
\hline 80 menit & 22 & 17 & 15 & 18 & 72 \\
\hline $\begin{array}{c}100 \\
\text { menit }\end{array}$ & 24 & 20 & 19 & 21 & 84 \\
\hline $\begin{array}{c}120 \\
\text { menit }\end{array}$ & 25 & 24 & 22 & 24 & 96 \\
\hline
\end{tabular}

2. Hasil pengamatan nyamuk yang mati setelah pemajanan dosis $15 \%, 20 \%$ dan $25 \%$ ekstrak daun bunga tahi kotok (Tagetes erecter) pada perlakuan, dapat dilihat pada tabel di bawah ini :
Tabel 4

Pengamatan Jumlah Kematian Nyamuk Dengan Ekstrak Daun Tahi Kotok 15\%

\begin{tabular}{|c|c|c|c|c|c|}
\hline \multirow[t]{2}{*}{$\begin{array}{l}\text { Waktu } \\
\text { pengamatan }\end{array}$} & \multicolumn{3}{|c|}{$\begin{array}{l}\text { Jumlah Nyamuk } \\
\text { Yang Mati } \\
\text { Dalam Tiga } \\
\text { Replikasi } \\
\text { (Ekor) }\end{array}$} & \multirow[t]{2}{*}{$\begin{array}{l}\text { Rata } \\
- \\
\text { rata }\end{array}$} & \multirow[t]{2}{*}{$\begin{array}{l}\text { Perse } \\
\text { ntase } \\
\text { (\%) }\end{array}$} \\
\hline & I & II & III & & \\
\hline 20 menit & 2 & 2 & 2 & 2 & 8 \\
\hline 40 menit & 4 & 5 & 5 & 5 & 20 \\
\hline 60 menit & 7 & 10 & 9 & 9 & 36 \\
\hline 80 menit & 11 & 12 & 14 & 12 & 48 \\
\hline 100 menit & 14 & 15 & 15 & 15 & 60 \\
\hline 120 menit & 16 & 17 & 17 & 17 & 68 \\
\hline
\end{tabular}

Sumber: Data Primer 2018

Tabel 5

Pengamatan Jumlah Kematian Nyamuk

Dengan Ekstrak Daun Tahi Kotok 20\%

\begin{tabular}{|c|c|c|c|c|c|}
\hline \multirow[t]{2}{*}{$\begin{array}{c}\text { Waktu } \\
\text { pengamata } \\
n\end{array}$} & \multicolumn{3}{|c|}{$\begin{array}{l}\text { Jumlah } \\
\text { Nyamuk } \\
\text { Yang Mati } \\
\text { Dalam Tiga } \\
\text { Replikasi } \\
\text { (Ekor) }\end{array}$} & \multirow[t]{2}{*}{$\begin{array}{l}\text { Rat } \\
\text { a- } \\
\text { rata }\end{array}$} & \multirow[t]{2}{*}{$\begin{array}{c}\text { Persentas } \\
\text { e }(\%)\end{array}$} \\
\hline & $\mathrm{I}$ & II & III & & \\
\hline 20 menit & 3 & 2 & 3 & 3 & 12 \\
\hline 40 menit & 5 & 6 & 7 & 6 & 24 \\
\hline 60 menit & 9 & 9 & $\begin{array}{l}1 \\
2\end{array}$ & 10 & 40 \\
\hline 80 menit & $\begin{array}{l}1 \\
3\end{array}$ & $\begin{array}{l}1 \\
4\end{array}$ & $\begin{array}{l}1 \\
4\end{array}$ & 14 & 56 \\
\hline 100 menit & $\begin{array}{l}1 \\
6\end{array}$ & $\begin{array}{l}1 \\
7\end{array}$ & $\begin{array}{l}1 \\
6\end{array}$ & 16 & 64 \\
\hline 120 menit & $\begin{array}{l}1 \\
8\end{array}$ & $\begin{array}{l}1 \\
9\end{array}$ & $\begin{array}{l}1 \\
9\end{array}$ & 19 & 76 \\
\hline
\end{tabular}

Sumber: Data Primer 2018 
Jurnal Sulolipu : Media Komunikasi Sivitas Akademika dan Masyarakat

Vol. 19 No.12019

e-issn : 2622-6960, p-issn : 0854-624X

Tabel 5.5

Pengamatan Jumlah Kematian Nyamuk Dengan Ekstrak Daun Tahi Kotok 25\%

\begin{tabular}{|c|c|c|c|c|c|}
\hline \multirow[t]{2}{*}{$\begin{array}{c}\text { Waktu } \\
\text { pengamatan }\end{array}$} & \multicolumn{3}{|c|}{$\begin{array}{l}\text { Jumlah } \\
\text { Nyamuk Yang } \\
\text { Mati Dalam } \\
\text { Tiga Replikasi } \\
\text { (Ekor) } \\
\end{array}$} & \multirow[t]{2}{*}{$\begin{array}{c}\text { Rata } \\
- \\
\text { rata }\end{array}$} & \multirow[t]{2}{*}{$\begin{array}{c}\text { Perse } \\
\text { ntase } \\
(\%)\end{array}$} \\
\hline & I & II & III & & \\
\hline 20 menit & 5 & 4 & 3 & 4 & 16 \\
\hline 40 menit & 10 & 7 & 8 & 8 & 32 \\
\hline 60 menit & 16 & 10 & 12 & 13 & 52 \\
\hline 80 menit & 20 & 15 & 15 & 17 & 68 \\
\hline 100 menit & 22 & 19 & 17 & 19 & 76 \\
\hline 120 menit & 24 & 22 & 20 & 22 & 88 \\
\hline
\end{tabular}

Sumber: Data Primer 2018

Tabel 7

Hasil PengukuranSuhu dan Kelembaban

\begin{tabular}{ccc}
\hline Reflikasi & $\begin{array}{c}\text { Hasil } \\
\left({ }^{\circ} \mathrm{C}\right)\end{array}$ & Kelembaban (\%) \\
\hline I & 32 & 64 \\
II & 32 & 62 \\
III & 33 & 62 \\
Rata -rata & $\mathbf{3 2 , 3}$ & $\mathbf{6 2}$ \\
\hline
\end{tabular}

\section{PEMBAHASAN}

1. Kemampuan ekstrak daun Lavender (Lavandula angostafolia) $15 \% 20 \%$ dan $25 \%$ sebagai ekstrak anti nyamuk dalam membunuh nyamuk

Pada pemajanan dosis $15 \% 20 \%$ dan $25 \%$ ekstrak daun Lavender dengan waktu pengamatan selama 2 jam dinyatakan mampu dalam mematikan nyamuk yang mana rata-rata kematian nyamuk pada dosis $15 \%$ dengan 3 kali replikasi sebanyak 18 ekor hal ini menunjukkan bahwa di dalam ruang kotak percobaan terdapat aroma menyengat dari proses pemanasan yang dihasilkan oleh proses penguapan sehingga semakin lama waktu pemaparan nyamuk semakin tinggi pula jumlah kematian nyamuk karena aroma yang dikeluarkan semakin menyengat pada ruang kotak percobaan yang menyebabkan nyamuk mati satu persatu.

Sama halnya dengan ekstrak $15 \%$ pada pemajanan ekstrak $20 \%$ dengan pengamatan 2 jam setelah ekstrak mencapai Lethal Dosis $50\left(\mathrm{LD}_{50}\right)$ dimana nyamuk yang mati rata - rata mencapai 20 ekor $(80 \%)$ dengan tiga kali pengulangan. Hal ini berarti bahwa lama waktu kontak berpengaruh terhadap kematian nyamuk dan semakin tinggi pula dosis suatu ekstrak semakin mempengaruhi jumlah kematian nyamuk, dimana semakin lama waktu kontak nyamuk terhadap ekstrak daun Lavender semakin mempengaruhi jumlah kematian nyamuk sehingga ekstrak daun lavender dengan dosis $20 \%$ diinyatakan lebih efektif dibanding ekstrak $15 \%$ sebagai anti nyamuk uap dalam membunuh nyamuk.

Begitu pula pada pemajanan dosis $25 \%$ ekstrak daun Lavender dengan waktu pengamatan selama 2 jam setelah mencapai Lethal Dosis $50\left(L_{50}\right)$ dimana nyamuk yang mati rata - rata mencapai 24 ekor $(96 \%)$ dengan tiga kali pengulangan. Hal ini berarti bahwa lama waktu kontak berpengaruh terhadap kematian nyamuk dan semakin tinggi pula dosis suatu ekstrak semakin mempengaruhi jumlah kematian nyamuk, dimana semakin lama waktu kontak nyamuk terhadap ekstrak daun lavender semakin mempengaruhi jumlah kematian nyamuk sehingga ekstrak daun bunga Lavender (Lavandula angostafolia) dengan dosis $25 \%$ diinyatakan lebih efektif di banding dosis $15 \%$ dan $20 \%$ sebagai anti nyamuk uap dalam membunuh nyamuk. Hal ini membuktikan bahwa semakin tinggi dosis suatu larutan semakin efektif pula dalam mematikan nyamuk.Berdasarkan Kriteria Obyektif Dinyatakan Mampu apabila ekstrak daun lavender dan ekstrak bunga tahi kotok yang diujikan dengan 25 ekor nyamuk dalam kurungan mati dalam jumlah $\geq 50 \%$.

2. Kemampuan ekstrak daun bunga Tahi Kotok (Tagetes arektes) $15 \% 20 \%$ dan $25 \%$ sebagai ekstrak anti nyamuk dalam membunuh nyamuk

Pada pemajanan dosis ekstrak daun bunga tahi kotok dengan dosis $15 \%$, $20 \%$, dan $25 \%$ dengan waktu pemajanan 
sama selama 2 jam dinyatakan mampu, namun terdapat perbedaan kematian nyamuk pada tiap dosis pada dosis $15 \%$ dengan tiga kali replikasi rata-rata nyamuk yang mati untuk 20 menit pertama sebanyak 2 ekor menunjukkan bahwa di dalam ruang kotak percobaan terdapat aroma menyengat dari proses penguapan ekstrak. Setelah 120 menit pengamatan dimana nyamuk yang mati rata - rata mencapai 17 ekor (68\%) dengan tiga kali pengulangan. Hal ini berarti bahwa lama waktu kontak berpengaruh terhadap kematian nyamuk, dimana semakin lama waktu kontak nyamuk terhadap ekstrak daun bunga tahi kotok semakin mempengaruhi jumlah kematian nyamuk sehingga ekstrak daun bunga tahi kotok dengan dosis $15 \%$ diinyatakan mampu sebagai anti nyamuk uap dalam membunuh nyamuk.

Begitu pula pada pemajanan ekstrak $20 \%$ denganwaktu pengamatan yang sama selama 2 jam, dimana nyamuk yang mati rata - rata mencapai 19 ekor (76 $\%)$ dengan tiga kali pengulangan, Hal ini berarti bahwa lama waktu kontak berpengaruh terhadap kematian nyamuk dan semakin tinggi pula dosis suatu ekstrak semakin mempengaruhi jumlah kematian nyamuk, dimana semakin lama waktu kontak nyamuk terhadap ekstrak daun bunga tahi kotok semakin mempengaruhi jumlah kematian nyamuk sehingga ekstrak daun bunga tahi kotok dengan dosis $20 \%$ diinyatakan lebih efektif di banding $15 \%$ sebagai anti nyamuk uap dalam membunuh nyamuk.

Pada ekstrak dengan dosis 25\% dengan waktu pengamatan yang sama selama 2 jam dengan interval waktu 20 menit yaitu rata - rata nyamuk yang mati Setelah 120 menit pengamatan dimana nyamuk yang mati rata - rata mencapai 22 ekor $(88 \%)$ dengan tiga kali pengulangan, namun 3 ekor nyamuk yang berada dalam kurungan yang belum mati hinggap ketepi dan sudah tidak bisa terbang namun belum mati. Hal ini berarti bahwa lama waktu kontak berpengaruh terhadap kematian nyamuk dan semakin tinggi pula dosis suatu ekstrak semakin mempengaruhi jumlah kematian nyamuk, dimana semakin lama waktu kontak nyamuk terhadap ekstrak daun bunga tahi kotok semakin mempengaruhi jumlah kematian nyamuk sehingga ekstrak daun bunga tahi kotok dengan dosis 25\% diinyatakan lebih efektif di banding 15 \%dan $20 \%$ sebagai anti nyamuk uap dalam membunuh nyamuk,Karena pada dosis $25 \%$ kematian nyamuk mencapai $88 \%$. Sehingga dapat disimpulkan bahwa pada ekstrak daun bunga tahi kotok dengan konsentrasi $15 \%, 20 \%$ dan 25\% dinyatakan mampu untuk mematikan nyamuk karena telah mencapai Lethal Dosis $50\left(\mathrm{LD}_{50}\right)$, dimana Lethal Dosis 50 adalah konsentrasi tertentu suatu bahan yang mampu mematikan sebanyak 50\% dari hewan percobaan.

Pada tabel 1 menunjukkan ratarata penurunan tiap ekstrak, yaitu pada ekstrak daun bunga tahi kotok rata - rata penurunan yaitu $4,78 \%$ sedangkan pada ekstrak daun Lavender lebih tinggi yaitu dengan rata - rata penurunan $8,56 \%$.

Selanjutnya pada hasil uji Independent Samples Test yang tercantum pada lampiran bahwa ekstrak daun bunga tahi kotok dan daun Lavender memiliki penurunan yang sama. Berdasarkan hasil yang diperoleh yaitu nilai sig $=, 010$. Hal ini berarti sig (014.) $<\alpha$ $(0,05)$, maka $\mathrm{H}_{0}$ ditolak. Jadi, dengan signifikasi ekstrak bunga daun tahi kotok dan ekstrak daun lavender didapatkan kesimpulan bahwa dari kedua ekstrak tersebut memiliki penurunan jumlah yang tidak sama atau ada perbedaan.

3. Perbandingan kemampuan ekstrak daun lavender (Lavandula angostafolia) dan ekstrak daun bunga tahi kotok (Tagetes erecta).

Bila dibandingkan antara ekstrak daun bunga tahi kotok (Tagetes arecter) dan daun Lavender (Lavandula angostafolia), daun Lavender lebih efektik atau ada perbedaan di antara kedua ekstrak tersebut. pembandingnya dapat dilihat pada konsentrasi $15 \%$ bunga tahi kotok rata-rata kematian nyamuk 17 ekor dari III kali replikasi untuk konsentrasi 15 $\%$ daun lavender rata-rata kematian nyamuk mencapai 18 ekor dari III kali replikasi. Untuk ekstrak daun bunga tahi kotok dengan konsentrasi $20 \%$ kematian nyamuk rata-rata 19 ekor dan untuk daun 
Jurnal Sulolipu : Media Komunikasi Sivitas Akademika dan Masyarakat

Vol. 19 No.12019

e-issn : 2622-6960, p-issn : 0854-624X

Lavender rata-rata kematian nyamuk mencapai 20 ekor, Sedangkan untuk konsetrasi $25 \%$ dari bunga tahi kotok ratarata kematian nyamuk mencapai 23 ekor dan untuk daun lavender rata-rata kematian nyamuk mencapi 24 ekor dengan masing-masing melakukan III kali replikasi. Hal ini membuktikan jika ekstrak daun lavender lebih efektif dibandingkan dengan ekstrak daun bunga tahi kotok.

Selain itu disebabkan karena tanaman lavender mempunyai kairomon sebagai zat kimia yang menimbulkan aroma yang tidak disenangi oleh nyamuk. Tanaman lavender juga mempunyai kandungan aktif berupa flavonoid; rosmarinic acid,chlorogenic acid, caffeic acid 2-(3,4-dihydroxyphenyl) ethenyl ester (terdapatpada bunga), flavonoid; hypolaetin, scutellarein, salvigenin, malvidin, xanthomicrol, delphinidine (terdapat padadaun), dan terpenoi; linalil asetat,linalol, 1,8-cineole, camphor, ursolic acid, oleanolic acid yang bersifat sebagai repellent (penolak serangga) dengan cara kerja sebagai racun kontak dan racun, pernapasan (Kherissat, 2009).

Selain itu berdasarkan penelitian dari Dinata (2005) . menyimpulkan bahwa Linalil asetat dan Linalol yang terdapat pada bunga lavender (Lavandula agustifolia) menghasilkan minyak yang digunakan sebagai bahan penolak serangga (repellant dan antifeedant), bahkan termasuk bahan yang sering digunakan sebagai lotion anti nyamuk.Sama halnya dengan daun bunga tahi kotok (Tagetes ereta) memiliki kandungan bau busuk yang sangat tidak disukai oleh nyamuk,bidang pertanian, bunga Tagetes efektif dalam pencegahan nematoda pengganggu tanaman sehingga digunakan sebagai tanaman tumpang sari, penangkal serangga, herbisida dan anti jamur. Minyak atsiri dari bunga tagetes efektif menghambat pertumbuhan bakteri, antijamur pada saprolegnia, ferax serta sebagai larvasida pada culex quinquefasciatus, dan Aedes aegypti (Anonim I, 2010).

Penelitian yang dilakukan sebelumnya oleh Dewi Widya Hana, (2016),penelitian dilaksanakan di ruang asrama jurusan Kesehatan Lingkungan
Poltekkes Denpasar. Ruangan yang digunakan adalah ruangan yang dipergunakan sebagai tempat tidur. Yang mana tiap kurungan pada ruangan tidur di isi 25 ekor nyamuk yang dikembang biakkan dari jentik dan dibiarkan satu hari dalam kurungan agar bisa beradaptasai. Hal ini menunjukkan bahwa terdapat perbedaan kemampuan membunuh Nyamuk. Daun memiliki kemampuan paling tinggi dengan nilai rata-rata 13 ekor, sedangkan akar untuk tanaman Tahi kotok mampu membunuh nyamuk rata-rata 5,75 ekor.bila dilihat dari efektifitas insektisida dari LD-50 maka memiliki rata-rata kemampuan membunuh nyamuk sebesar $52 \%$.

Insektisida nabati merupakan bahan alami, bersifat mudah terurai di alam (biodegradable) sehingga tidak mencemari lingkungan dan relatif aman bagi manusia maupun ternak karena residunya mudah hilang (Naria, 2005). Cara pembuatan insektisida nabati dari berbagai jenis tumbuhan tidak dapat dijelaskan secara khusus atau distandarisasi karena memang sifatnya tidak berlaku secara umum. Pembuatan insektisida nabati dapat di lakukan secara sederhana atau secara laboratorium. Cara sederhana (jangka pendek) dapat di lakukan dengan penggunaan ekstrak sesegera mungkin setelah pembuatan ekstrak di lakukan.

Pada dasarnya penggunaan insektisida kimia dapat membahayakan kelangsungan hidup manusia, binatang dan mahluk hidup lainnya. Mengingat dampak negatif yang dapat terjadi, maka perlu digunakaan alternatif lain. Penggunaan insektisida nabati merupakan salah satu alternatif yang dapat dilakukan, sebab insektisida nabati lebih aman karena residunya mudah hilang, dan mudah terurai (biodegradable) sehingga tidak mencemari lingkungan (Kardinan, 2004).Penggunaan ekstrak Daun bunga tahi Kotok dan Bunga Lavender sebagai anti nyamuk dengan metode ionisasi dalam membunuh nyamuk merupakan salah satu alternatif yang paling efektif untuk mengurangi pencemaran lingkungan. Selain itu insektisida nabati hanya meninggalkan sedikit residu pada 
Jurnal Sulolipu : Media Komunikasi Sivitas Akademika dan Masyarakat

Vol. 19 No.12019

e-issn : 2622-6960, p-issn : 0854-624X

komponen lingkungan sehingga dianggap lebih aman daripada insektisida kimia, zat insektisida nabati lebih cepat terurai dialam sehingga tidak menyebabkan resistensi pada sasaran. Selain itu dapat dibuat sendiri dengan cara sederhana,bahan mudah didapatkan disekitar rumah, dan lebih ekonomis.

Nyamuk merupakan binatang berdarah dingin, proses dan siklus kehidupannya tergantung pada suhu lingkungan. Sehingga dalam penelitian ini terlebih dahulu dalam mendesain kotak percobaan dengan mempertimbangkan kebutuhan udara ruang kotak percobaan,maka pada setiap ruang dilengkapi dengan ventilasi $10 \%$ dari luas lantai permukaan kotak percobaan. Kemudian untuk mengetahui secara akurat suhu pada ruang kotak percobaan dilakukan pengukuran. Adapun hasil pengukuran suhu ruang penelitian, yang diukur selama melakukan penelitian diperoleh rata-rata suhu ruangan adalah $32,3{ }^{\circ} \mathrm{C}$ dengan kondisi suhu ruangan tersebut sesuai untuk kelangsungan kehidupan nyamuk sehingga tidak mempengaruhi perkembangan dan pertumbuhan nyamuk dikarenakan masih pada kisaran suhu optimal yang berkisar antara $25-35^{\circ} \mathrm{C}$.

Suhu merupakan salah satu faktor penting yang harus diperhatikan agar tidak mempengaruhi proses pengujian nyamuk terhadap mekanisme kerja dari bahan insektisida nabati. Suhu ruang yang tinggi ataupun rendah akan mempengaruhi kelansungan hidup nyamuk . bila suhu selalu lebih dari $27-30{ }^{\circ} \mathrm{C}$, umur nyamuk akan menjadi lebih pendek (Sumantri, 2015).

Selanjutnya kelembaban pada dasarnya kelembaban berbanding terbalik dengan suhu apabila suhu tinggi maka kelembaban rendah begitupun sebaliknya. Hasil pengukuran kelembaban udara dalam ruangan penelitian selama melakukan percobaan yaitu rata-rata kelembaban ruangan penelitian tersebut yaitu sekitar $62 \%$ Kelembaban juga merupakan salah satu kondisi lingkungan yang dapat mempengaruhi perkembangan nyamuk. Pada kelembaban kurang dari 60 $\%$ umur nyamuk akan menjadi pendek, tidak bisa menjadi vektor, tidak cukup waktu untuk perpindahan virus dari lambung ke kelenjar ludah.

\section{PENUTUP}

\section{KESIMPULAN}

Berdasarkan hasil penelitian ini, dapat disimpulkan bahwa ekstrak daun Lavender dan ekstrak daun bunga tahi kotok dapat dikatakan mampu dalam mematikan nyamuk pada dosis $15 \%$, $20 \%$, dan $25 \%$ dengan tiga kali replikasi dan telah mencapai LD50.

\section{SARAN}

a. Hasil penelitian ini diharapakan dapat menjadi suatu alternatif pengendalian vektor khususnya terhadap nyamuk ekstrak Daun Lavender Dan ekstrak daun bunga tahi kotok dapat difungsikan sebagai insektisida nabati .

b. Penelitian ini mengunakan ekstrak Daun Lavender Dan ekstrak daun bunga tahi kotok diharapkan agar peneliti selanjutnya dapat meneliti kemampuan kedua ekstrak tersebut tanpa menggunakan bahan kimia seperti methanol. Dan mengetahui seberapa lama ekstrak dapat bertahan dengan volume $100 \mathrm{ml}$.

c. Untuk pemerintah atau petugas kesehatan dapat dijadikan sebagai sumber informasi kepada masyarakat untuk menggunakan bahan insektisida nabati yang ramah lingkungan.

\section{DAFTAR PUSTAKA}

Dantje T. Sambel. 2009. Entomologi kedoktereran. Yokyakarta : CV. Andi offset.

BPS.2015. Jumlah Kasus Penyakit Menurut Provinsi Dan Jenis Penyakit. Makassar :Badan Pusat Statistik

Dewi hasan, dkk. 2012. Pemanfaatan Akar Dan Daun Tahi Kotok (Tagetes arectes) Dalam Mematikan Nyamuk Aedes. Jurnal ilmu hayati dan fisik.Jurusan Kesehatan Lingkungan. 
Jurnal Sulolipu : Media Komunikasi Sivitas Akademika dan Masyarakat

Vol. 19 No.12019

e-issn : 2622-6960, p-issn : 0854-624X

Poltekkes Semarang. (online).http://www.jurnalws.ums.ac.id. 16(2). Diakses pada tanggal 12 Oktober 2017.

Dewi, Meilina Yuhanita. 2013. Perbedaan Kemampuan Daya Tolak Minyak Atsiri Bunga Melati (Jasminum Sambac) Dan Daun Selasih (Ocimum Basilicum) Sebagai Repelen Nyamuk Aedes Aegypti.Gema Kesehatan Lingkungan. (online).http://www.diglib.poltekkesdepkessby.ac.id. 10 (1). Diaskes 3 Mei 2017.

Dinata Arna. 2005. Efektivitas Ekstrak Tanaman Zodia (Evodia suaveolens) Pada berbagai konsentrasi repelent Terhadap Aktivitas Menghisap Darah Nyamuk Aedes aegypti. Skripsi. Universitas Kristen Maranatha. (online).https://www.scribd.com .Diaskes 3 Desemberi 2017.

Dewi Widya Hana. 2016. Perbedaan Bilangan Peroksida Pada Minyak Jelantah Setelah penumbukan bubuk daun tahi Kotok (Tagetes erecta). Skripsi.Politehnik Kementerian Kesehatan Denpasar. (online).https://www.media.neliti.com .Diaskes 3 Mei 2018.

Dini Nuris Nuranni. 2002. Aneka Manfaat Bunga Untuk Kesehatan. Yokyakarta : Penerbit Gava Media.

H. Danang Iskandar, dkk. 1985. Pemberantasan Serangga Dan Binatang Pengganggu. Proyek Pengembangan Pendidikan Tenaga Sanitasi Jakarta : Pusat Depertemen Kesehatan RI.

Kardinan, Agus. 2006. Tanaman Pengusir Dan Pembasmi Nyamuk. Jakarta: Argomedia Pustaka.

Karwati. 2008. Tanaman Pengusir Nyamuk. (online). http://www.google.co.id. Diakses 10 Oktober 2017.

Komisi Pestisida Departemen Pertanian. 2012. Metode Standar Pengujian Efikasi Pestisida. Jakarta :Departemen Pertanian. 95 halaman.

Marganta A. 1996. Mewaspadai Demam Berdarah. Solo: Penerbit CV Aneka.

Naria.2005. Insektisida Nabati UntukRumah Tangga. FakultasKesehatan Masyarakat.Universitas Sumatera Utara. (Online) http://repository.usu.ac.id/.Diakses pada 24 juni 2017.

Nurul Fahmi, 2017. Efektivitas Daun Dan Bunga Tanaman Sukunn(Artocarpus Altilis) Sebagai Anti Nyamuk Mat Elektrik Dalam Membunuh Nyamuk Aedes Aegypti. Skripsi. Jurusan Kesehatan Lingkungan Politehnik Kesehatan Makassar.

O'Connor, dan Sopa, 1981. A checklist of mosquitoes of indonesia. 2. Jakarta : Us- Namru.

Republik Indonesia. 2012. Depertemen Kesehatan Republik Indonesia. Laporan Jumlah Penderita Penyakit Yang disebabkan oleh nyamuk. Jakarta :Depkes.

Republik Indonesia.2010.Peraturan Menteri Kesehatan Republik Indonesia Nomor 374 tahun 2010 Tentang Pengendalian Vektor.

Singgih dan upik. 2006. Hama Permukiman Indonesia. Bogor : Unit Kajian Pengendalian Hama (UKPHP).

Soedarto. 1995. Entomologi Kedokteran. Jakarta: Penerbit Buku Kedokteran EGG :63.

Suharto Zen, Dkk. 2016. Potensi Ekstrak Bunga Tahi Kotok (Tagetes Erecta) Sebagai Repellent Terhadap Nyamuk Aedes Aegypti Yang Aman Dan Ramah Lingkungan. Jurnal 
Jurnal Sulolipu : Media Komunikasi Sivitas Akademika dan Masyarakat

Vol. 19 No.12019

e-issn : 2622-6960, p-issn : 0854-624X

Pendidikan Biologi. Universita Muhammadiyah Metro. (Online).http://www.researchgate.net.Diakses pada 18 November 2017.

Sumantri, Arif.2015.Kesehatan Lingkungan.Edisi Ketiga.Jakarta: Kencana Prenada Media Group.

Yesi Hijriah Perdani. 2015. Efektifitas Tanaman Lavender Terhadap Populasi Nyamuk Di Desa Meri RT 02 RW 01 Kecamatan Magersari Kota Mojokerto. Penelitian Pengendalian. (Online)http://www.jurnalws.ums.ac.id. Diaskes 2 Januari 2018. 